FACTA UNIVERSITATIS

Series: Economics and Organization Vol. 16, No 3, 2019, pp. 239 - 254

https://doi.org/10.22190/FUEO1903239D

Original Scientific Paper

\title{
IMPROVING PERFORMANCE OF VAT SYSTEM IN DEVELOPING EU COUNTRIES: ESTIMATING THE DETERMINANTS OF THE RATIO C-EFFICIENCY IN THE PERIOD 1997-2017
}

\author{
UDC 336.226.322
}

\section{Marina Đorđević, Jadranka Đurović Todorović, Milica Ristić*}

University of Niš, Faculty of Economics, Niš, Serbia

\begin{abstract}
Indirect taxes have a significant place in developing EU countries' tax systems. The article sums up works by different scientists, dealing with the impact of VAT efficiency determinants. The purpose of this study is to investigate the determinants of VAT collection efficiency in the EU developing countries. The study relies on relevant data in transparent international statistical databases, covering the period from 1997 to 2017. The main research question in this paper is: does rise in value added tax rate negatively affect VAT collection efficiency in the EU developing countries. Accordingly, one of the independent variables included in the survey is standard annual VAT rate. In addition to standard VAT rate, as a determinant of VAT collection efficiency, we analyze: economic growth rate, export of goods, export of services, wages and salaries, household consumption. The hypotheses set are analyzed using correlation and regression analyses. Empirical results show a positive effect of economic growth rate, export of goods, and the negative effect of two variables: standard VAT rate and household consumption. The two observed variables, export of services and wages and salaries, do not show a statistically significant effect. The results obtained using appropriate statistical tools serve as guidelines to macroeconomic policy makers to generate higher tax revenues from VAT. By analyzing the $C$-efficiency determinant, we design a relevant development strategy approach for economically underdeveloped EU countries.
\end{abstract}

Key words: value-added tax (VAT), performance of VAT, C-efficiency ratio, developing countries

JEL Classification: H2, H21, O52

Received April 24, 2019 / Accepted June 17, 2019

* PhD student at University of Niš, Faculty of Economics, Serbia

Corresponding author: Marina Đorđević

University of Niš, Faculty of Economics, Trg kralja Aleksandra Ujedinitelja 11, 18000 Niš, Serbia

E-mail: marina.dj@ptt.rs 


\section{INTRODUCTION}

Value added tax is, according to many theorists, the most important tax revenue in developing countries (Bird, 1987; Cnossen, 1988; Gilbert, 1995; Alan, 1999; Ebrill et al., 2002; Minh Le, 2003; Emran \& Stiglitz, 2004; Grandcolas, 2005; Hillman, 2009; Keen, 2013; Đurović Todorović, Đorđević \& Ristić, 2019; Bikas \& Anduskaite, 2013; Izedonmi \& Okunbor, 2014; Hajdúchová, Sedliačiková \& Viszlai 2015; Andrejovská \& Mihoková, 2015). A well-known British economist, Owens (2011), states that value added tax (VAT) today "accounts for one-fifth of the total tax revenue". Apodictically, VAT is a tax whose lucrative character has led to its application in more than 150 countries around the world.

Research shows that VAT is the most profitable tax form in developing countries (Đurović Todorović, Đorđević \& Ristić, 2019, p. 234), and, for this reason, the importance of VAT is highlighted in these countries' tax systems. Developing countries can collect significantly higher tax revenues by indirect taxes, compared to direct taxes. Restrictions on the financing of public spending by direct taxes correspond to the level of their development. However, it often happens that developing countries do not collect sufficient funds by indirect taxes either. This is mainly the result of global economic and financial crises, which in most cases end with fiscal implications. In order to cover their fiscal deficits, developing countries either turn to borrowing or increase tax rates. The lack of tax revenues can also be noticed in situations where "the government does not redistribute tax revenue and when it has to increase revenues to finance public goods" (Stiglitz, 2002, p. 484). As VAT has the largest share in indirect taxes, developing countries provide for their goods by increasing standard VAT rate.

"Increasing standard VAT rate was one of the basic ways to tackle the problem of insufficient public revenues recorded before the 2008 crisis" (Keen, 2013, p. 423). Therefore, both developed and developing countries increased their standard VAT rate. Most of the countries did not see alternative ways to increase VAT revenues. The captious question that arose in academic circles was: is rise in standard VAT rate the most effective solution to generate higher tax revenues? The polygon for these surveys was mainly found in developing countries, and the responses, which resulted from empirical research, were generally negative. Increasing standard rate is the simplest solution, but it is not feasible in all circumstances. Increased standard rates in developing countries, which already have the highest rates, trigger the problem of tax avoidance and rising tax evasion. This list of negative effects resulting from high VAT rates does not end here in countries where this is the main source of revenue. Rise in tax evasion creates an unfavorable business environment, as well as a field for gray economy. A more efficient option to increase VAT revenue is to improve VAT performance. "Improving performance involves expansion of the tax base, limited use of reduced rates and exemptions, more productive tax administration, better compliance of legislation and practice" (Owens, 2011a, p. 8).

In order to ensure optimum tax revenues, VAT performance, i.e. VAT collection efficiency, is the subject of numerous theoretical, empirical, and experimental studies today. Given that economic development of underdeveloped countries is determined by a welldesigned VAT system, it is very important that VAT collection efficiency is at a satisfactory level. "The development of tools that explain the differences in VAT performance has over the past few years received considerable practical attention. The need for conceptual development of these tools is the result of a tendency to increase VAT revenues without compromising other policy objectives" (Keen, 2013a). The aim of this paper is to 
investigate factors that influence VAT collection efficiency, which will be one of the options for increasing tax revenues. The starting point is the fact that studies dealing with VAT collection efficiency factors are scarce. We focus on the underdeveloped countries of the European Union, because these countries "experienced significant government changes during economic transformation" (Bayar, 2016, p. 6). The main objective of this study is to investigate factors that influenced VAT collection efficiency during the period 1997-2017. We focus on Greece and Hungary, which were among the first countries to introduce the VAT system in the 1980s, then Estonia, Slovakia, the Czech Republic, Poland, Romania, and Bulgaria, countries that introduced the VAT to join the EU in the 1990s, as well as Latvia, Lithuania, and Slovenia, which have recently incorporated VAT. In particular, we want to answer the following questions. First, which empirical link exists between analyzed independent variables, GDP growth rate, standard VAT rate, export of goods, export of services, wages and salaries, household consumption, and VAT collection efficiency in underdeveloped EU countries? What factors determine VAT collection efficiency and the way to generate higher tax revenues? We also want to show negative effects of higher standard rates on VAT collection efficiency. Section II provides an overview of existing literature on determinants of VAT collection efficiency. Section three presents empirical methodology and model evaluation. Finally, section IV gives conclusion.

\section{FACTORS AFFECTING VAT COLLECTION EFFICIENCY: LITERATURE REVIEW}

Consumption taxes, especially value added tax, first gained academic attention in 1980s. Numerous studies speak of the role of value added tax and its obvious administrative advantages in national development (Bird, 1987). However, despite the importance of increasing the revenue coming from this form of taxation, studies on the factors that determine VAT collection efficiency are scarce. "The importance of value added tax in the economy is recognized, but this tax form is mainly analyzed only in terms of tax rate, tax relief, and tax threshold" (Bikas \& Andruskiate, 2013, p. 41). Some authors emphasize the great impact of VAT collection efficiency on revenue collection (Keen \& Lockwood, 2010), but, at the same time, there is a relatively small number of empirical studies that examine determinants of VAT collection efficiency.

The first theorists who investigated VAT collection efficiency were Agha and Haughton (1996). The purpose of their study was to, through a cross-country analysis, investigate determinants that affect VAT compliance. They pay special attention to multiple tax rates, as well as to high tax rates. Observing the example of the OECD countries, using the 1987 data, the authors note that VAT collection efficiency is determined by standard rate level, number of rates, administration, and the period of VAT application in a country. VAT collection efficiency would be enhanced by a lower standard VAT rate, smaller number of tax rates, longer application period, and better tax administration.

Bogetić and Hassan (1993) investigate the basic determinants of VAT revenue, analyzing the statistics of 34 countries. Their research involves 20 countries with a single rate and 14 countries using multiple rates. Theorists, among other things, give an answer to the question whether there is a statistically significant difference in VAT performance between countries with a single VAT rate and countries with a multiple VAT rate. The results of their regression model show that key variables that affect the performance of VAT revenue are: rate, tax base, and rate dispersion. The determinant, whose character 
the authors emphasize, is VAT rate. According to their estimator model, countries with tax systems involving a single VAT rate may have higher VAT revenues. They point out that their results are crucial in creating a tax policy in developing countries planning to introduce a single tax rate in their tax systems.

Agha and Haughton (1996a) analyze VAT collection efficiency determinants, using the 1987 statistics of 17 OECD countries. The authors conceive the index of compliance, regressed against determinants. They pay particular attention to what happens if the country introduces multiple rates, as well as to the effects of high VAT rates. The results of the regression analysis show that efficiency can be improved with a lower VAT rate, fewer rates, smaller population, more learning time, and greater spending on administration.

Ebrill et al. (2002) investigate the basic factors behind the relatively high level of Cefficiency and conclude that a high level of trade share, high literacy rates, and the time period of VAT application are crucial for VAT revenues.

Aizenman and Jinjarak (2005) investigate the connection between several factors and VAT collection efficiency. They base their research on statistical data in the 1970-1999 period. The survey covers the statistics of 44 countries and uses panel regression. The analysis includes Estonia, Greece, Hungary, and Poland. The authors examine the following explanatory variables: real GDP per capita, share of agriculture, trade development and level of urbanization, measures of political instability and the degree of political regulation. The estimator models their research uses are the Fixed Effects model and the OLS model. They find a strong link between trade development, political regime sustainability, and VAT collection efficiency.

Hybka (2009) analyzes the relationship between VAT collection efficiency and estimated factors in the European Union countries, with focus on Poland. The author points out that Polish VAT collection efficiency is influenced by changes in terms of VAT system harmonization with the EU, economic growth rate trends, and changes in domestic demand. In Poland, Hybka concludes, VAT collection efficiency is also influenced by standard rate level.

Based on the VAT structure in Lithuania, Bikas and Rashkauskas (2011) investigate factors that affect VAT collection efficiency. Their analysis, based on quarterly statistical data, encompasses the period 1995-2009 and contains the appropriate regression model. Independent variables included in the model are: standard VAT rate, difference between standard VAT rate and reduced VAT rate (excluding zero rate), and unemployment. The results of regression analysis show a positive and statistically significant effect of standard rate as well as the difference between standard rate and reduced VAT rate on VAT collection efficiency. Also, the results show a negative and statistically significant effect of unemployment on VAT collection efficiency.

Đurović Todorovic and Đorđević (2013), based on the 2009 C-efficiency analysis in 14 countries, conclude that the average value of the C-efficiency ratio depends on the reduced rates, exemptions, level of tax evasion, and inefficient tax administration.

Tagkalakis (2014) analyzes factors that influence VAT collection efficiency in Greece. He focuses on VAT collection efficiency determinants using quarterly data on VAT revenue, private consumption, and GDP (2000: Q1-2012: Q3). In addition, the regression model includes the following dummy variables: elections in Greece and situation after implementing measures to improve administration revenues and combat tax evasion, which Greece had to implement during the EU-IMF monitoring (since May 2010). The main goal is to investigate VAT collection efficiency in good and bad economic conditions. The dependent variable, Cefficiency ratio, is expressed by the following equation: VAT Consumption $\mathrm{C}$ efficiency $=$ 
(VAT revenue / private consumption) / standard tax rate $* 100$. The results of the regression analysis carried out using OLS technique show a positive and statistically significant relationship between the analyzed variables. The author finds that the growth of real GDP growth rate by $1 \%$ increases VAT collection efficiency on average by 0.63 percentage points. The author concludes that when there are poor economic conditions in the country, VAT collection efficiency is at a much lower level. Additionally, research points to another factor that can reduce VAT collection efficiency, namely the ability to combat tax evasion. Deterioration in these abilities in one country implicitly reduces VAT collection efficiency.

Sancak et al. (2010) carry out a panel data analysis of VAT C-efficiency determinants, using data from the EU countries in the period 1995-2008. They divide their analysis into three data sets, including, among others, the countries whose estimator model we are exploring. The first data set contains annual data on $32 \mathrm{EU}$ countries during the period 1995-2008; the second data set consists of the annual data of 84 developed and developing countries and encompasses the same time period; the third data set includes quarterly data on 37 developed and developing countries during the period 1999-2009. Using correlation and regression analysis, they find a strong positive correlation between revenue and output gap. The results of their regression analysis show that "shifts in consumption patterns towards goods and services with lower VAT rates and higher tax evasion during economic expansions are key channels through which the output gap affects VAT C-efficiency". During the period of expansion, households tend to get the goods they need, and these goods are in most economies taxed at minimum rates or are not taxed. A good example is the Baltic countries, Estonia, Latvia, and Lithuania, which faced the biggest impact of the global economic crisis. They also find that VAT C-efficiency is positively correlated with institutionally regulated administration and is in a negative correlation with the overall tax burden in one economy.

Sokolovska and Sokolovskyi (2015) study VAT collection efficiency, analyzing tax collection efficiency around the world. They investigate the dependence between $\mathrm{C}$ efficiency and the level of gray economy and corruption in countries.

Numerous studies point to basic factors that affect VAT collection efficiency, excluding the group of countries studied in this paper. Antic (2014) investigates VAT efficiency in Bosnia and Herzegovina. Bosnia and Herzegovina is also a developing country that faced a sharp decline in VAT collection efficiency at the onset of the global economic crisis. Since this developing country had high $\mathrm{C}$-efficiency, the decline in this ratio during periods of crisis has raised many questions in academic circles. The author decomposes C-efficiency in Bosnia and Herzegovina to prove that the VAT design cannot provide a high level of VAT collection efficiency. The research results show that deviations from the VAT law, debt growth, and tax evasion have the biggest impact on gap growth. Analogously, the author concludes that high VAT rates deepen the crisis and cannot improve VAT collection. Hodzic and Celebi (2017) investigate VAT collection efficiency in 28 EU countries, with a particular focus on Turkey during the 2009-2013 period, giving a comparative picture of Cefficiency in Turkey and other EU countries. Based on the VAT revenues in various countries and different levels of C-efficiency, they conclude that Turkey needs greater stability and efficiency of the VAT collection system. Grandcolas (2005) analyzes Cefficiency in 15 Pacific countries (Papua New Guinea, Jamaica, Trinidad, Mauritius, Fiji, Cyprus, Malta, Iceland, Barbados, Vanuatu, Samoa, Tonga, Cook Islands, Niue). The author presents C-efficiency ratio as a share of VAT revenues in GDP to standard rate. The author includes a C-efficiency ratio in his study to explore the experience of countries that 
abandoned the VAT system. A special research focus is on Malta, Grenada, and Ghana. He concludes that the VAT system works if there is a strong obligation of political authorities and a detailed plan and resources for VAT implementation. Bird and Gendron (2006) investigate VAT collection efficiency in 24 countries (Argentina, Barbados, Bolivia, Brazil, Canada, Chile, Colombia, Costa Rica, Dominican Republic, Ecuador, El Salvador, Guatemala, Haiti, Honduras, Jamaica, Mexico, Nicaragua, Panama, Paraguay, Peru, Suriname, Trinidad and Tobago, Uruguay, Venezuela), assessing C-efficiency as the most reliable indicator of VAT collection efficiency. The most important explanatory variables that influence VAT collection efficiency are, according to these authors, urbanization and real GDP per capita.

Finally, we also pay attention to the latest research in this field. Sarmento (2016) investigates the crucial factors that affect VAT revenue. In this way, the author highlights the importance of VAT collection efficiency. His research relies on panel data analysis of 27 countries, in the timeframe 1998-2011. Sermento explores the countries of the European Union and finds that EU governments in most cases rely on increasing tax rates in order to raise a higher amount of tax revenues. The author divides all independent variables into several groups: 1) VAT rates, 2) economic variables, 3) efficiency of administration, using the C-efficiency ratio, 4) legal and institutional environment. The research results show that the efficiency of tax administration (the C-efficiency ratio) is a key determinant in collecting VAT revenues. Ueda (2017) analyzes Japan in addition to EU countries. Ueda explores the impact of compliance and policy gaps following the example of the EU and Japan over the period 2000-2014, and finds strong causality of both gaps, compliance gap and policy gap. The focus of this study is on the fluctuations of C-efficiency, resulting from changes in final consumption and standard rate.

\section{C-EFFICIENCY RATIO AS AN INDICATOR OF VAT EFFICIENCY}

There are several indicators of VAT collection efficiency. A retrospective presentation of VAT collection efficiency formula is found in a survey conducted by Sokolovska and Sokolovskyi (2015a). The authors sum up all previous studies of the relevant VAT collection efficiency indicator. Đurović Todorović and Đorđević (2013a) also point to some of the measures of VAT collection efficiency. One of the ways in which VAT collection efficiency can be considered is based on the share of VAT revenue in the GDP of a country. However, this indicator does not show if VAT collection efficiency is unsatisfactory. The more subtle indicator is the traditional efficiency measure.

The traditional measure of VAT collection efficiency, efficiency ratio, is presented in the following formula.

$$
\text { efficiency ratio }=\frac{V A T \text { Revenue } / G D P}{S R}
$$

Where VAT revenue is tax revenue generated from VAT; GDP - Gross domestic product; $\mathrm{SR}$ - standard VAT rate.

Ebrill et al. (2002a) point to the shortcomings of this indicator. In their opinion, traditional efficiency measure tends to increase VAT collection efficiency in one country. The main disadvantage of the "traditional" indicator is in the numerator. VAT collection efficiency can be increased, because numerator includes production, while VAT is a tax form that explicitly applies to consumption. 
A significant diagnostic tool, which will include only consumption in the numerator, instead of production, is a C-efficiency ratio. The basic formula to calculate C-efficiency, according to Keen (2013b), can be presented as follows:

$$
C-\text { efficiency ratio }=\frac{V}{P V^{T}}
$$

Numerator V represents realized VAT revenues; while $P V^{T}$ can be calculated as follows:

$$
P V^{T} \equiv \tau^{S}(F C-V) \text {. }
$$

$P V^{T}$ represents theoretical VAT revenue; $\tau^{S}$ is a standard VAT rate ${ }^{2}$; FC represents final consumption (Keen $2013 \mathrm{c}$, p. 427). ${ }^{3}$

"This ratio measures the difference between the actually collected revenue and the amount of VAT revenues that could theoretically be collected if the standard rate was applied to the entire tax base" (Đurović Todorović \& Đorđević, 2013b, p. 92). If VAT gap is higher, this indicates that the potential of this tax form is unused. However, in spite of the authors' consent that this ratio is a relevant indicator of efficiency, the ratio analysis must contain a certain level of reserve. Sancak et al. (2010a) find that deterioration (improvement) of ratio is often conditioned by changes in consumption patterns or changes in tax evasion during expansion. Consequently, it is necessary, in the course of the crisis, to include effects of capital consequences in the analyses. Sokolovska and Sokolovsky (2015b) also speak about the negative link between tax evasion and this ratio, suggesting that a large part of the evaded revenues is used for consumption, which ultimately reflects on this ratio. With a certain level of reserve, and taking into consideration $\mathrm{C}$-efficiency defects that are difficult to measure, we will explore factors that determine VAT collection efficiency based on C-efficiency.

\subsection{Measurement of C-efficiency ratio in EU developing countries}

The European idea of greater economic integration got a new concept on May 1, 2004, when 8 former centrally planned economies from Central and Eastern Europe - the Czech Republic, Poland, Hungary, Slovakia, Slovenia, Lithuania, Latvia, and Estonia become members of the European Union (Njegić et al., 2017). The VAT implementation in the EU's developing countries is related to their simplified tax systems" (Andrejovska \& Mihokova, 2015, p. 488). Such reforms have made it possible for developing countries to open their economies. In previous years, VAT has become the basic source of revenue in all EU member states (European Commission, 2019). "According to various analyses, VAT is the best form of consumption tax" (Bird \& Gendron, 2006a, p. 2). As such, VAT has, over the past twenty years, reached "share in total tax revenues of almost $65 \%$ " (Owens, 2011b, p. 8). However, one captious question that arises here is whether the VAT system is well designed in all countries where the VAT is implemented, i.e. whether the VAT collection efficiency is at a satisfactory level.

The following graph shows the trend of C-efficiency in the period 1997-2017 in the observed developing countries of the EU.

\footnotetext{
${ }^{2}$ In our study, the annual VAT standard rate of each country is used in the calculation of VAT.

${ }^{3}$ According to Keen (2013), final consumption involves: consumption by households, the government, and nonprofit serving households (NPISH).
} 


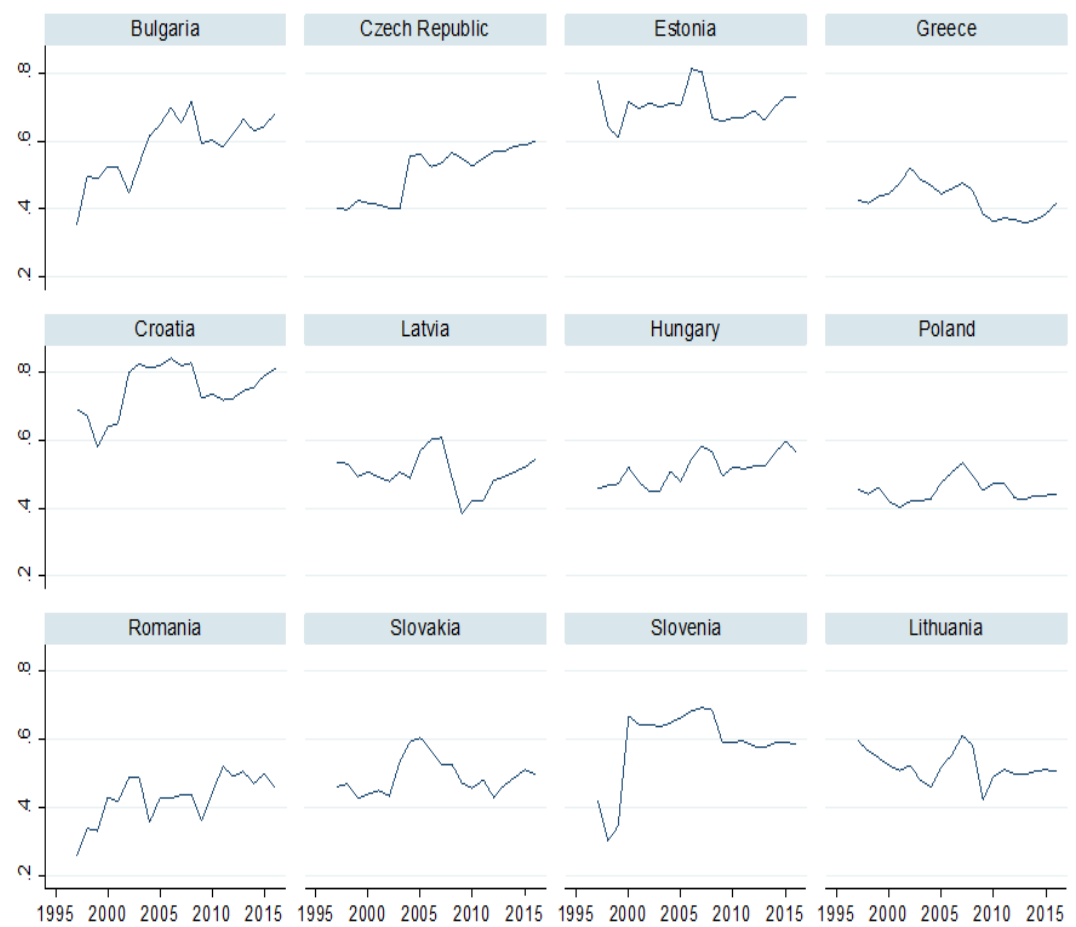

Fig. 1. The C-efficiency trend in the observed countries in the period 1997-2017 Source: Eurostat; European Commission; Own calculations.

"Empirical studies show the connection between VAT collection efficiency in one country and the level of its development" (Minh Le, 2003, p. 2). Based on the trends of the relevant indicator, VAT collection efficiency in developing countries is different. The highest VAT collection efficiency in the last analyzed year is in Croatia (0.80) and the lowest in Greece (0.41). Croatia has recorded growth in C-efficiency over the past few years, which is in line with the country's GDP growth rate in the same period. At the same time, a country that is famous for the negative GDP growth rates and the growing public debt is undoubtedly Greece. Judging by such circumstances in the country, a logical conclusion is the low value of $\mathrm{C}$-efficiency ratio.

In Bulgaria, one can notice a very cyclical trend of C-efficiency ratio. If we look at Bulgaria's tax policy, tax rate changes can be one of the important factors of these cyclical trends (European Commission, 2019). The growth trend of the efficiency indicator in the Czech Republic can also be observed in line with the standard VAT rate trend. In the years that followed the reduction in the rate, the $\mathrm{C}$-efficiency ratio showed positive discrepancy.

Large cyclical changes can be seen in Romania and Hungary, which may be associated with frequent changes in the standard and reduced VAT rates in these countries. In addition, the global economic crisis of 2008 left the consequences on fiscal and financial stability in Romania (Oprea, 2013, pp. 176-177; Popa, 2014). A sharp fall in C-efficiency can, therefore, be related to the consequences described in Oprea et al. (2013a). 
When it comes to Lithuania, VAT revenue has been falling since 2001. The reason for the reduction of VAT revenues in the national budget of Lithuania can be explained by the situation at that time, and is related to the harmonization of taxes, in accordance with EU legal acts. Harmonization implied changes in VAT rates (tariff), and "VAT revenues largely depend on the number of taxes applied, the amount, and the tax base to which the reduced rates are applied" (Bikas, 2011). Period from 2004-2008 is considered to be a period of economic growth in Lithuania, when consumption grew, and so did the value of C-efficiency (Bikas, 2011a). "Estonia, Latvia, and Lithuania are the countries that experienced the greatest impact of the global economic crisis during 2008-09" (Sancak et al., 2010b, p.4), and what explicitly followed in these countries was the fall in VAT collection efficiency. VAT collection efficiency in Poland was the highest in 2007, which is in line with the growth of Poland's GDP. When it comes to Slovenia, we note that the C-efficiency ratio in 2009 was significantly lower than in the previously analyzed years. This drop can be associated with the negative GDP growth rate in the country, which was very low in 2009 (-7.8\%). Effects of changes in tax policy are also evident in Slovakia. The reduction of the VAT rate $(2003,2004)$ was accompanied by an increase in the ratio value, while increase in the VAT rate (2011) came with the fall in the ratio value.

\subsection{Implications of standard VAT rate on the ratio}

"Increasing the standard VAT rate is one of the easiest ways to increase tax revenue, especially when governments in developing countries are trying to find ways to finance large fiscal deficits" (Owens, 2011c, p. 8). The graph shows the standard VAT rate trend in the analyzed EU countries in the 1997-2017 timeframe.

Graph 2 and Graph 1 show that, in most countries, rise in the standard VAT rate is followed by the falling trend of C-efficiency. Greece has had the most changes in tax policy,

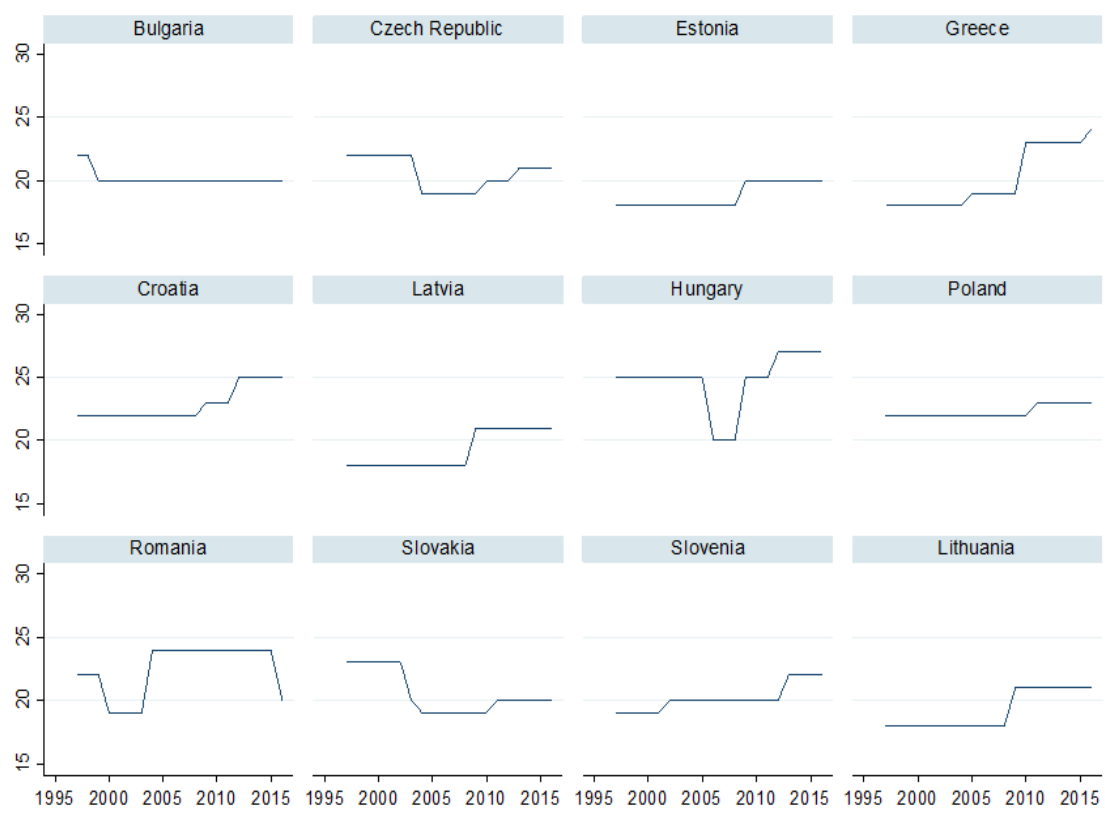

Fig. 2 Standard VAT rate trends in the observed countries (in \%), 1997-2017. Source: Eurostat; European Commission; Authors' calculations. 
with explicitly the lowest ratio value in the analyzed period (1997-2016). The highest standard VAT rate, not only in the analyzed countries, but also in the EU, is in Hungary (27\%).

Table 1 The introduction of the VAT system in the developing EU countries and current standard rate (in \%)

\begin{tabular}{lcc}
\hline Country & Year of VAT introduction & Standard rate (in \%) \\
\hline Bulgaria & 1994 & 20 \\
Czech Republic & 1993 & 21 \\
Estonia & 1991 & 20 \\
Greece & 1987 & 24 \\
Croatia & 1998 & 25 \\
Latvia & 1995 & 21 \\
Hungary & 1988 & 27 \\
Poland & 1993 & 23 \\
Romania & 1993 & 19 \\
Slovakia & 1993 & 20 \\
Slovenia & 1999 & 22 \\
Lithuania & 1994 & 21 \\
\hline
\end{tabular}

Source: European Commission, 2019.

Table 1 shows the years of VAT introduction into the tax system of the countries analyzed, as well as the VAT rate in 2017. The lowest VAT rate is applied in Romania. "Only two EU countries have changed the tax rate in 2017: Greece (from 23\% to 24\%) and Romania (from 20\% to 19\%)" (European Commission, 2019). The answer to the question of whether the standard rate is an important determinant of VAT collection efficiency is analyzed in the following section.

\section{DATA, ECONOMETRIC METHODOLOGY AND EMPIRICAL ANALYSIS}

The research sample of our statistical data includes 12 developing countries, members of the European Union: Bulgaria, Czech Republic, Estonia, Greece, Croatia, Latvia, Hungary, Poland, Romania, Slovakia, Slovenia, Lithuania. Statistical data consists of annual data for the period from 1997 to 2017. We investigate the impact of 6 indicators on VAT collection efficiency in EU transition economies. Dependent variables whose impact will be assessed are: GDP growth rate, standard VAT rate, export of goods, export of services, wages and salaries, and household consumption. The dependent variable, VAT collection efficiency, will be expressed using formulas for calculating C-efficiency, (2) and (3).

\subsection{Data}

The aim of this paper is to evaluate the basic determinants of VAT collection efficiency. To calculate dependent variables, we collect data on realized annual VAT revenues, final consumption expressed in millions of euros, and data on the annual standard VAT rate trend in each country. Explanatory variables used in the econometric analysis are given in the following table. 
Table 2 Review of explanatory variables

\begin{tabular}{lccc}
\hline Independent variables & Symbol/Abbereviation & Calculation & Source \\
\hline $\begin{array}{l}\text { Gross domestic product } \\
\text { Standard VAT rate }\end{array}$ & $\begin{array}{c}\text { GDPgrowth } \\
\text { VATrate }\end{array}$ & $\begin{array}{c}\text { Annual growth rate } \\
\text { Annual rate of each } \\
\text { country }\end{array}$ & $\begin{array}{c}\text { Eurostat } \\
\text { European Commission } \\
\text { - Taxation and } \\
\text { Customs Union }\end{array}$ \\
Export of goods & EG & Percentage share of GDP & Eurostat \\
Export of services & ES & Percentage share of GDP & Eurostat \\
Wages and salaries & WS & Percentage share of GDP & Eurostat \\
Household consumption & C & Percentage share of GDP & Eurostat \\
\hline
\end{tabular}

Source: Author's illustration.

Combining time series and comparative data decreases the possibility of multicollinearity (Jovičić \& Dragutinović Mitrović, 2011, p. 217). This creates the basis to conduct panel data analysis of 12 EU countries for the period 1997-2017, using StataSE (release 13). Before selecting the model to be evaluated, a correlation analysis is conducted, to point to the possibility of a multicollinearity problem. The correlation analysis ranges from -1 to +1 , and the value of the coefficient determines the strength of the correlation (Bhattacherjee, 2012, p. 123). The correlation matrix is presented in Table 3.

Table 3 Correlation matrix of the used variables

\begin{tabular}{|c|c|c|c|c|c|c|c|}
\hline & $\begin{array}{c}\text { C-efficiency } \\
\text { ratio }\end{array}$ & $\begin{array}{l}\text { GDP } \\
\text { growth }\end{array}$ & VATrate & EG & ES & WS & $\mathrm{C}$ \\
\hline C-efficiency ratio & 1.0000 & & & & & & \\
\hline GDP growth & $\begin{array}{c}0.1504 \\
(0.0197)\end{array}$ & 1.0000 & & & & & \\
\hline VATrate & $\begin{array}{l}-0.1457 \\
(0.0240)\end{array}$ & $\begin{array}{c}-0.2804 \\
(0.0000)\end{array}$ & 1.0000 & & & & \\
\hline EG & $\begin{array}{c}0.2054 \\
(0.0014)\end{array}$ & $\begin{array}{c}0.0173 \\
(0.7899)\end{array}$ & $\begin{array}{c}0.0437 \\
(0.5502)\end{array}$ & 1.0000 & & & \\
\hline ES & $\begin{array}{c}0.4446 \\
(0.0000)\end{array}$ & $\begin{array}{c}0.0096 \\
(0.8825)\end{array}$ & $\begin{array}{l}-0.0514 \\
(0.4280)\end{array}$ & $\begin{array}{l}-0.0451 \\
(0.4866)\end{array}$ & 1.0000 & & \\
\hline WS & $\begin{array}{c}0.3477 \\
(0.0000)\end{array}$ & $\begin{array}{c}-0.0559 \\
(0.3945)\end{array}$ & $\begin{array}{c}0.0733 \\
(0.2642)\end{array}$ & $\begin{array}{c}0.1472 \\
(0.0243)\end{array}$ & $\begin{array}{c}0.3454 \\
(0.0000)\end{array}$ & 1.0000 & \\
\hline $\mathrm{C}$ & $\begin{array}{l}-0.2880 \\
(0.0000)\end{array}$ & $\begin{array}{l}-0.0085 \\
(0.8954)\end{array}$ & $\begin{array}{l}-0.1261 \\
(0.0510)\end{array}$ & $\begin{array}{l}-0.6129 \\
(0.0000)\end{array}$ & $\begin{array}{l}-0.2374 \\
(0.0002)\end{array}$ & $\begin{array}{c}-0.3446 \\
(0.0000)\end{array}$ & 1.0000 \\
\hline
\end{tabular}

Based on Table 3, we conclude that there is a significant degree of agreement between individual indicators and C-efficiency. The results show direction and strength of linear correlation between the analyzed variables. The results of the correlation analysis point to an agreement between the C-efficiency ratio and the GDP growth rate (GDPgrowth). The Pearson's coefficient points to a positive correlation (0.1504) at a significance level of $5 \%(\mathrm{p}<0.05)$. There is a positive correlation between C-efficiency and the export of goods (EG) (Pearson's correlation coefficient is 0.2054 , at a significance level of $5 \%$ (p $<0.05$ ). Also, there is a positive correlation between C-efficiency and export of services (ES) (Pearson's correlation coefficient is 0.4446 , at a significance level of $1 \%(\mathrm{p}<0.001)$. 
Analogously, the positive correlation exists between C-efficiency and the wages and salaries (WS) ratio $(\mathrm{p}<0.001)$. A negative correlation exists between C-efficiency and consumption based on the Pearson's coefficient $(-0.2880)$, at the level of statistical significance of $1 \%(\mathrm{p}<0.001)$, as well as between C-efficiency and the standard VAT rate (Pearson's coefficient of correlation is 0.1457 , at the significance level of $5 \%(\mathrm{p}<0.05)$.

\subsection{Econometric methodology and empirical analysis}

Since the correlation analysis indicates that there are significant interdependencies between the analyzed variables, we select the appropriate model. Before we interpret the results of regression analysis, we show which model best suits the analyzed data. There are several types of appropriate panel models: The Pooled Regression Model (Pooled), the Fixed Effect Model (FEM), and the Random Effect Model (REM). These model types are determined by their parameters. The Pooled model is a model with constant regression parameters. The Fixed model is a model with regression constant variability. Third, but not in order of significance, is the Random model, which does not indicate the variability of a constant in any dimension.

In order to obtain the relevant results of the panel analysis, we carry out research using strongly balanced data. The first step in the panel analysis of time series involves testing individual and time effects using the F-test (Jovičić \& Dragutinović Mitrović, 2011a, p. 243). The F test is a tool by which we choose between two models: the Pooled or the FEM model. In the event that the zero hypothesis cannot be rejected, we use the Pooled model. However, the Pooled model will not explain the differences between the observed units, in particular, the differences that exist between the countries. In the event that the zero hypothesis is rejected, the constant is not the same for all observation units, but varies. In such a situation, we apply a fixed-effects model (FEM), to determine differences between countries. A Breusch-Pagan LM test is used to decide between the Pooled or REM models. In order to determine whether the variability relates only to a constant or also to a regression parameter with an independent variable, we apply the Breusch-Pagan LM test (Jovičić \& Dragutinović Mitrović, 2011, p. 247). In the event that the zero hypothesis cannot be rejected, the Pooled, or a model with constant regression parameters, should be applied. If the zero hypothesis is rejected, we apply the REM model. It is possible that the results of the conducted tests indicate that both the FEM and REM models can be relevant for the interpretation of the regression analysis. In that case, it is necessary to continue the testing using the Hausman test. The Hausman test will examine which alternative is the best, i.e. what differences exist in the assessment of the fixed and random effect models. If the zero hypothesis is rejected, it is inevitable that the fixed effect model should be applied. On the other hand, we apply the random effect model (REM).

The research results are shown in Table 4. The model results are the FEM model results, showing that the average value of the coefficient varies between countries.

Table 4 Results of the test for choosing the suitable model

\begin{tabular}{cccc}
\hline & F-test & Breusch-Pagan LM & Hausman \\
& $\mathrm{H}_{0}$ : Pooled, $\mathrm{H}_{1}:$ FEM & $\mathrm{H}_{0:}$ Pooled, $\mathrm{H}_{1}$ : REM & $\mathrm{H}_{0}$ : REM, $\mathrm{H}_{1}$ : FEM \\
\hline Model & 5.01 & 4.29 & 29.01 \\
& $(0.0000)$ & 0.0191 & $(0.0001)$ \\
\hline
\end{tabular}

Note: $\mathrm{p}$ values in ().

Source: Authors' calculations. 
The results obtained by the regression analysis are presented in Table 5. The model explains $46.17 \%$ of changes in the C-efficiency ratio and is statistically significant at a significance level of $1 \%$.

Table 5 Results of regression analysis

\begin{tabular}{cc}
\hline Independent variable Ratio c efficiency & Dependent variable \\
\hline Constant & 1.325429 \\
& {$[4.80]$} \\
& $(0.000)$ \\
GDPgrowth & 0.0040728 \\
& {$[2.29]$} \\
VATrate & $(0,023)$ \\
& -0.008913 \\
& {$[-1.69]$} \\
EG & $(0.093)$ \\
& 0.0016631 \\
C & {$[2.51]$} \\
& -0.0126943 \\
& {$[-3.95]$} \\
Note: $t$ statistic in [], p values in (). & $(0.000)$ \\
Source: Authors' calculations.
\end{tabular}

The results of the estimated fixed effect regression model (FEM) show that the coefficients of the observed independent variables, which can be seen in Table 5, are statistically significant in explaining the $\mathrm{C}$-efficiency ratio. If the gross domestic product growth rate increases by $1 \%$, the C-efficiency ratio will increase by an average of $0.40728 \%$, ceteris paribus ( $\mathrm{p}<0.05$ ). If the exports of goods as a percentage of GDP increases by $1 \%$, the Cefficiency ratio will increase by an average of $0.16631 \%$, ceteris paribus $(p<0.05)$. The other two explanatory variables have a statistically significant negative effect on the C-efficiency ratio. If the standard VAT rate increases by $1 \%$, the C-efficiency ratio will decrease by an average of $0.8913 \%$, ceteris paribus ( $\mathrm{p}<0.10$ ). If household consumption as a percentage of GDP increases by $1 \%$, the C-efficiency ratio will decrease by an average of $1.26943 \%$, ceteris paribus ( $p<0.001)$. Independent variables, wages and salaries and export of services, expressed as a percentage of GDP, do not show a statistically significant impact.

\section{CONCLUSION}

The regression analysis has highlighted the following statistically significant factors for increasing the VAT collection efficiency in developing countries: GDP growth rate, standard VAT rate, export of goods as a percentage of GDP, and household consumption as a percentage of GDP. Given that authors do not fully agree on the importance of different VAT collection efficiency determinants, this paper has investigated the impact of explanatory variables on VAT revenues in economically underdeveloped countries over the period 1997-2017. The subject of our analysis has been explanatory variables, which are in correlation with the analyzed indicator of VAT collection efficiency. 
"The limitations that accompany this research are tax evasion and various tax exemptions, which differ between countries" (Aizenman \& Jinjarak, 2005, p. 14).

As an indicator of VAT collection efficiency, we have determined the C-efficiency ratio. This ratio, using the appropriate variables, best illustrates whether VAT collection in one country is at a satisfactory level. Since C-efficiency is obtained using the standard VAT rate, the same variable has been one of our explanatory variables. By incorporating the standard VAT rate in the analysis, we answered one of the research questions set: is the increase in the standard VAT rate an efficient way to achieve optimal tax revenues? The aim of our research was to point out the negative effects of a high standard rate and to explore relevant factors for increasing VAT revenue through C-efficiency analysis. The results of the regression model explicitly show the negative impact of the standard VAT rate on C-efficiency. The standard VAT rate and C-efficiency are in a negative correlation. In this sense, the paper highlights consequences of inadequately conceived tax policy for the economic growth of the underdeveloped countries of the European Union. If authorities increase tax rates, this explicitly leads to reduction in VAT collection efficiency, and, ultimately, reduced tax revenues in the budget.

The correlation analysis has established an empirical link between the analyzed independent variables and VAT collection efficiency. The VAT collection efficiency in developing countries is affected by GDP growth rates. Accordingly, in line with GDP growth, $\mathrm{C}$-efficiency will be at a higher level, i.e. VAT collection efficiency will be higher. There is a negative and statistically significant effect of household consumption on C-efficiency. Specifically, an increase in household consumption decreases C-efficiency. Excessive increase in consumption can create indications of the existence of tax evasion. Sokolovska and Sokolovskyi (2015) indicate that a large part of evaded revenues are used for consumption, and this in the end has reflections on C-efficiency. Furthermore, this can be explained by the negative correlation between household consumption and economic growth rate. Export of goods positively affects VAT collection efficiency. Increase in export increases VAT collection efficiency. The two variables we observed did not show a statistically significant effect on VAT collection efficiency: export of services and wages and salaries.

We hope that answers to the questions set will be guidelines for governments in shaping tax policies. The study of VAT collection efficiency factors has added up to empirical research in the field of the most profitable consumption tax in developing countries, and gave an overview of the existing literature on the observed problem.

\section{REFERENCES}

Agha, A. \& Haughton, J. (1996). Designing Vat Systems: Some Efficiency Considerations, The Review of Economics and Statistics, 78 (2), 303-308.

Aizeman, J. \& Jinjarak, Y. (2008). The Collection Efficiency of the Value Added Tax: Theory and International Evidence, The Journal of International Trade and Economic Development, 17 (3), 391-410.

Andrejovska, A. \& Mihokova, L. (2015). Developments of VAT rates in EU countries in the context of harmonization and fiscal consolidation, Acta Universitatis agriculturae et silviculturae mendelianae brunensis, 63 (2), 487-498.

Antić, D. (2014). Efficiency of a single rate and broad based VAT system: the case of Bosnia and Herzegovina, Financial theory and Practice, 38 (3), 303-335.

Bank of Greece (2012). „Governor’s Annual Report for 2012“. Annex to Chapter IX: Tax policy changes, April. Bătrâncea, L. \& Nichita, A. (2015). Which is the best government? Colligating tax compliance and citizens' insights regarding authorities' actions, Transylvanian Review of Administrative Sciences, No. 44 E/2015, 5-22. 
Bhattacherjee, A. (2012). Social Science Research: Principles, Methods, and Practices. Textbooks Collection. Tampa, Florida: University of South Florida, Scholar Commons.

Bikas, E. \& Andruskaite, E. (2013). Factors affecting value added tax revenue, European Scientific Journal, special edition no. 1, 41-49.

Bikas, E. \& Rashkauskas, J. (2011). Value added tax dimension: The case of Lithuania, Ekonomika, 90 (1), 22-38.

Bird, R. \& Gendron, P.P. (2006). Is VAT the Best Way to Impose a General Consumption Tax in Developing Countries?, International Studies Program (Working Paper, 06-18), Georgia: Georgia State University.

Bird, R. \& Zolt, E. (2015). Fiscal Contracting in Latin America, World Development, 67 (2015), 323-335.

Bird, R. (1987). A New Look at Indirect Taxation in Developing Countries, World Development, 15(9), 1151-1161.

Bogetić, Ž. \& Hassan, F. (1993). Determinants of Value-Added Tax Revenue: A Cross-Section Analysis (World Bank Policy Research Working Paper, 1203), Washington: World Bank.

Brondolo, J. (2009). Collecting Taxes During an Economic Crisis: Challenges and Policy Options, IMF Staff Position Note, SPN/09/17, Washington: International Monetary Fund.

Canale R.R. \& Liotti, G. (2015). Discretionary Fiscal Policy Measures and Growth in the Selected Eurozone Countries, Stock and Forex Trading, 4 (2), 1-6.

Cheeseman, N. \& Griffiths, R. Increasing tax revenue in sub-Saharan Africa: The case of Kenya, The Oxford Council on Good Governance No. 6, 1-28.

Đurović Todorović, J. \& Đorđević, M. (2013). Porezi na potrošnju [Taxes on consumption]. Niš: Ekonomski fakultet.

Đurović Todorović, J., Đorđević, M. \& Ristić, M. (2019). Struktura savremenih poreskih sistema [The structure of modern tax systems]. Niš: Ekonomski fakultet.

Ebrill, L., Keen, M., Bodin, J.P. \& Summers, V. (2002). The Allure of the Value-Added Tax, Finance and development, A quarterly magazine of the IMF, June 2002, 39 (2).

Emran, M.S. \& Stiglitz, J. (2005). On selective indirect tax reform in developing countries. Journal of Public Economics, 89 (2005), 599-623.

European Commission (2019). VAT rates applied in the Member States of the European Union, Brussels: European Commission.

Fortuzi, S. \& Doda, S. (2015). Fiscal policy in Albania, International Journal of Economics, Commerce and Management, 3 (6), 627-633.

Grandcolas, C. (2005). The Occasional Failure in VAT Implementation: Lessons for the Pacific, Asia Pacific Tax Bulletin, 6-13.

Gupta, V. (1999). SPSS for Beginners. VJBooks Inc.

Hajdúchová, I., Sedliačiková, M. \& Viszlai, I. (2015). Value-added Tax Impact on the State Budget Expenditures and Incomes, Procedia Economics and Finance, 34 (2015), 676-681.

Hodzic, S. \& Celebi, H. (2017). Value added tax and its efficiency: EU-28 and Turkey, UTMS Journal of Economics, 8 (2), 79-90.

Hybka, M. (2009). Vat Collection Efficiency in Poland before and after accession to the European Union-A Comparative Analysis, Ekonomika, 2009 (85).

Izedonmi, F.I.O. \& Okunbor, J.A. (2014). The Roles of Value Added Tax in the Economic Growth of Nigeria. British Journal of Economics, Management and Trade, 12 (4), 1999-2007.

Jovičić, M. \& Dragutinović Mitrović, R. (2011). Ekonometrijski metodi i modeli [Econometric methods and models]. Beograd: Ekonomski fakultet.

Keen, M. \& Lockwood, B. (2010). The value added tax: Its causes and consequences. Journal of Development Economics, 92 (2), 138-151.

Keen, M. \& Smith, S. (2007). VAT fraud and evasion: What do we know and what can be done?. (IMF Working Paper, WP/07/31), Washington: International Monetary Fund.

Keen, M. (2007). VAT Attacks!, (IMF Working Paper, WP/07/142), Washington: International Monetary Fund.

Keen, M. (2013). The anatomy of the VAT. National Tax Journal, 66 (2), 423-446

Klun, M. (2003). Administrative Costs of Taxation in a Transition Country: The Case of Slovenia. Finance a úvûr, 53 (1-2), 75-84.

Le, M.T. (2003). Value Added Taxation: Mechanism, Design, and Policy Issues, Paper prepared for the World Bank course on Practical Issues of Tax Policy in Developing Countries, Washington D.C., 28 April.

Oprea, F., Mehdian, S. \& Stoica, O. (2013). Fiscal and financial stability in Romania-an overview. Transylvanian Review of Administrative Sciences, no. 40 E/2013, 159-182.

Owens, J. (2011). Improving performance of VAT systems. World Commerce Review, 5 (3), September 2011.

Popa, M. (2014). Taxes Fees and Obligations in Romania - Main Components of Companies Fiscal Costs. Procedia Social and Behavioral Sciences, 109 (2014), 150-154.

Sancak, C., Velloso, R. \& Xing, J. (2010). Tax Revenue Response to the Business Cycle (IMF Working Paper 10/71), Washington: International Monetary Fund. 
Sermento, J. (2016). The determinants of Value added tax revenues in the European Union. European Journal of Management Studies, 21 (2), 79-99.

Sokolovska, O. \& Sokolovskyi, D. (2015). VAT efficiency in the countries worldwide. Research Institute of Financial Law, State Fiscal Service of Ukraine, MPRA Paper no. 66422.

South Africa-Technical Assistance Report (2015). Revenue Administration Gap Analysis Program-The Value Added Tax Gap (IMF Country Report no. 15/180). Washington: International Monetary Fund.

Tagkalakis, A. (2014). The determinants of VAT revenue efficiency: recent evidence from Greece. Bank of Greece Working Paper, 181.

Ueda, J. (2017). The Evolution of Potential VAT Revenues and C-Efficiency in Advanced Economies (IMF Working Paper, WP/17/158). Washington: International Monetary Fund.

Yessegat, W.A. (2008). Value Added Tax Administration in Ethiopia. eJournal of Tax Research, 6 (2), 145-168.

\section{POBOLJŠANJE PERFORMANSI POREZA NA DODATU VREDNOST U ZEMLJAMA U RAZVOJU EVROPSKE UNIJE: PROCENA DETERMINANTI RACIA C-EFIKASNOSTI U PERIODU 1997-2017}

Indirektni porezi zauzimaju značajno mesto u poreskim sistemima zemalja u razvoju EU. Članak subsumira radove različitih naučnika, koji se bave uticajem determinant na efikasnost PDV-a. Svrha ovog istraživanja je da istraži determinante efikasnosti PDV-a u zemljama u razvoju koje su članice Evropske Unije. Glavno istraživačko pitanje u ovom radu je: da li povećanje stope poreza na dodatu vrednost negativno utiče na efikasnost PDV-a u zemljama u razvoju EU. U skladu sa tim, jednu od nezavisnih varijabli, koju smo uključili u istraživanje, predstavlja standardna godišnja stopa PDV-a. Pored standardne stope PDV-a, kao determinante efikasnosti PDV-a, analizirali smo: stopu privrednog rasta, izvoz dobara, izvoz usluga, plate i nadnice, potrošnju domaćinstva. Postavljene hipoteze analizirane su korelacionom i regresionom analizom. Istraživanje je sprovedeno korišćenjem relevantnih podataka iz transparentnih internacionalnih statističkih baza, u periodu od 1997-2017. Empirijski rezultati su pokazali pozitivan efekat stope privrednog rasta, izvoza dobara i negativan efekat dve varijable: standardne stope PDV-a i potrošnje domaćinstva. Dve posmatrane varijable, izvoz usluga $i$ plate i naknade, nisu pokazale statistički značajan efekat. Na osnovu rezultata regresionog modela, date su smernice kreatorima makroekonomske politike u cilju ostvarivanja većih poreskih prihoda od PDV-a $i$ ekonomskog razvoja analiziranih zemalja.

Ključne reči: porez na dodatu vrednost (PDV), performance $P D V$-a, racio c-efikasnosti, zemlje u razvoju 